\title{
PENDAMPINGAN ORANG TUA MEMBIMBING ANAK BELAJAR DARI RUMAH DI ERA WABAH COVID 19
}

\author{
Jeaprileni A. Eli Manafe ${ }^{1} \&$ Ezra Tari $^{2}$ \\ Institut Agama Kristen Negeri Kupang ${ }^{1 \& 2}$ \\ E-mail: jeprilenielimnafe@gmail.com ${ }^{1}$, tariezra@gmail.com ${ }^{2}$
}

\begin{abstract}
Abstrak
Sistem pembelajaran daring menuntut orang tua lebih banyak mendampingi anak dalam belajar. Namun, orang tua masih banyak yang merasa kewalahan untuk menjelaskan tugas yang diberikan guru lewat daring. Karena tidak semua orang tua mampu menjelaskan dengan baik tugas tersebut sehingga mereka marah kepada anak. Kajian ini berupaya memaparkan pendampingan orang tua selama pandemi covid-19. Penulis mengambil contoh di Sekolah Dasar Oebobo II. Studi ini memakai pendekatan kualitatif deskriptif analitis. Penguraian data yang didapatkan dari informan sesuai dengan pertanyaan penelitian. Hasil penelitian ditemukan bahwa, sarana dan prasarana belajar menjadi salah satu sumber utama dalam proses belajar. Bentuk pendampingan orang tua yakni, menyediakan fasilitas belajar berupa laptop, kuota internet, dan ruang belajar yang nyaman. Sehingga ada pemantauan dan kontrol untuk membantu anak yang mengalami kesulitan belajar. Komunikasi yang lancar antara guru dan orang tua menjadi jalan utama dalam proses pembelajaran yang baik.
\end{abstract}

Kata kunci: pembelajaran, pembimbingan, pendidikan

\begin{abstract}
The online learning system requires parents to accompany their children more in learning. However, many parents still feel overwhelmed to explain the tasks given by the teacher online. Parents feel overwhelmed because they have to accompany their children and explain the tasks given by the teacher. Because not all parents are able to explain the task well so they are angry with their children. The goal of this study is to describe parental help during the COVID-19 epidemic. The author uses the Oebobo II Elementary School as an example. This research employs a qualitative descriptiveanalytic technique. Decomposition of data obtained from informants in accordance with research questions. The study results found that learning facilities and infrastructure became primary sources in the learning process. The form of parental assistance provides learning facilities in laptops, internet quotas, and comfortable study rooms. So there is monitoring and control to help children who have learning difficulties. Smooth communication between teachers and parents is the leading way in a good learning process.
\end{abstract}

Keywords: learning, guidance, education 


\section{Pendahuluan}

Pendidik merupakan salah satu
unsur dalam lingkungan belajar.
Lingkungan belajar merupakan ruang
untuk memenuhi kebutuhan kognitif,
sosial, dan afektif. ${ }^{1}$ Pendidik yang
dimaksud merupakan orang yang
mempunyai keahlian dalam aspek
pembelajaran untuk memengaruhi orang
lain. Pengaruh tersebut bersifat dialogis
dengan berbagai pemangku kepentingan.
Sehingga kesuksesan prosedur pembelajaran, sungguh terkait pada kesiapan pengajar serta nara didik dalam menggunakan perlengkapan pembelajaran, contohnya; buku, alat tulis serta sejenisnya. Empat jenis tantangan umum yang dialami oleh nara didik adalah intrapersonal, interpersonal, komunitas sekolah, dan komunitas pendidik daring. ${ }^{3}$

Pengajaran disini tidak hanya mengarah pada pengembangan informasi namun menekankan makna untuk meningkatkan proses belajar nara didik. ${ }^{4}$ Kiat yang dibangun dari dalam diri nara

1 Torrey Trust et al., "\#RemoteTeaching \& \#RemoteLearning: Educator Tweeting During the COVID-19...," Journal of Technology and Teacher Education 28, no. 2 (2020): 151-159, accessed July 7, 2021, https://www.learntechlib.org/p/216094/.

${ }^{2}$ Birgitte Wraae dan Andreas Walmsley, "Behind the Scenes: Spotlight on the Entrepreneurship Educator," Education + Training 62, no. 3 (April 6, 2020): 255-270.

3 Jeffrey P. Carpenter dan Stephen Harvey, "“There's No Referee on Social Media': Challenges in Educator Professional Social Media Use," Teaching and Teacher Education 86, no. 1 (November 1, 2019): 1-12, accessed July 7, 2021, https://www.sciencedirect.com/science/article/abs/ pii/S0742051X1930455X.

${ }^{4}$ John Loughran dan Ian Menter, "The Essence of Being a Teacher Educator and Why It Matters," Asia-Pacific Journal of Teacher Education 47, no. 3 (May 27, 2019): 216-229, accessed July 7, 2021 ,

https://www.tandfonline.com/doi/abs/10.1080/135 9866X.2019.1575946. didik adalah gaya belajar. Strategi pendidik disini lebih menekankan implementasi dan hasil..$^{5}$ Perihal pengaruh gaya belajar ialah tempo belajar serta penentuan strategi belajar. Gaya belajar dalam skenario tatap muka dan daring merupakan metode belajar terkini dalam proses belajar mengajar. ${ }^{6}$ Pada pembelajaran, peran serta gaya belajar, daya cipta, komunikasi digital serta minat memengaruhi hasil belajar.

Sikap dan pekerjaan orang tua memiliki pengaruh positif terhadap prestasi belajar, namun gaya belajar tidak berpengaruh. ${ }^{8}$ Selain itu pembelajaran inklusi berkontribusi terhadap pencapaian peran kemajuan anak, baik dalam perspektif kognitif ataupun kemajuan yang lain. Keikutsertaan orang tua dalam proses belajar, tidak hanya pembiayaan

\footnotetext{
5 Antonette Shibani, Simon Knight, dan Simon Buckingham Shum, "Educator Perspectives on Learning Analytics in Classroom Practice," The Internet and Higher Education 46, no. 1 (July 1, 2020): 1-14, accessed July 7, 2021, https://www.sciencedirect.com/science/article/abs/ pii/S1096751620300063.

${ }^{6}$ Fareeha Rasheed dan Abdul Wahid, "Learning Style Detection in E-Learning Systems Using Machine Learning Techniques," Expert Systems with Applications 174, no. 1 (July 15, 2021): 112, accessed July 7, 2021, https://www.sciencedirect.com/science/article/abs/ pii/S0957417421002153.

Febrianti Maya Ida dan Hasan Maksum, "Contribution of Learning Style, Learning Creativity and Exploratory Interest to Students' Simulation and Digital Communication Learning Outcomes during the Covid-19 Pandemic," Journal of Education Technology 4, no. 4 (March 13, 2021): 404-414, accessed July 7, 2021, https://ejournal.undiksha.ac.id/index.php/JET/artic le/view/29701.

8 Ratrining Raras Irawati dan Zamroni, "The Effect of Multicultural Attitude, Learning Style, and Parents' Job on the Learning Achievement of the Students," Harmoni Sosial: Jurnal Pendidikan IPS 7, no. 2 (January 2, 2020): 160-169, accessed July 7 , 2021, https://journal.uny.ac.id/index.php/hsjpi/article/vie w/10218.
} 
semata. Keterlibatan orang tua sangat penting untuk pengembangan model pendidikan di masa depan. ${ }^{9}$

Keterlibatan orang tua dalam dunia pendidikan yakni sebagai pendidik dan memfasilitasi anak dalam belajar. Sehingga orang tua dapat mempraktikkan pembelajaran inklusi bagi anak-anak mereka. ${ }^{10}$ Salah satu strategi yang sangat efisien untuk dilakukan oleh orang tua di rumah ialah mempersiapkan ruang belajar yang mengasikkan serta mendukung dengan diiringi apresiasi yang positif. ${ }^{11}$ Orang tua telah bertahun-tahun menganggap bahwa mengajar anak adalah beban. Alasan tersebut tidak sepenuhnya diterima, karena tanggung jawab mengajar, mendidik dan membimbing menjadi tanggung jawab penuh orang tua. ${ }^{12}$

9 Alejandro Veas et al., "Relationship between Parent Involvement and Academic Achievement through Metacognitive Strategies: A Multiple Multilevel Mediation Analysis," British Journal of Educational Psychology 89, no. 2 (June 1, 2019): 393-411, accessed July 7, 2021, https://bpspsychub.onlinelibrary.wiley.com/doi/ful 1/10.1111/bjep. 12245 .

${ }^{10}$ Valerie Harwood dan Nyssa Murray, "Strategic Discourse Production and Parent Involvement: Including Parent Knowledge and Practices in the Lead My Learning Campaign," International Journal of Inclusive Education 23, no. 4 (April 3, 2019): 353-368, accessed July 7, 2021, https://www.tandfonline.com/doi/abs/10.1080/136 03116.2019.1571119.

${ }^{11}$ Frederik Patar Hutahaean and Talizaro Tafonao, "Urgenitas Keterlibatan Orang Tua Dalam Menangani Psikologi Anak Selama Belajar Di Masa Pandemi," Kapata: Jurnal Teologi dan Pendidikan Kristen 2, no. 1 (2021): 13-26, accessed September 7, 2021, http://jurnalsttba.ac.id/index.php/KJTPK/article/view/16.

${ }^{12}$ Rismag Dalena Florentina Monica Br Manurung and Talizaro Tafonao, "Problem Pembelajaran Online Di Masa Pandemi Terhadap Psikologi Anak Usia 10-12 Tahun," Matheteuo: Religious Studies 1, no. 1 (June 1, 2021): 20-28, accessed September 7 , 2021 ,
Pada masa pandemi ini, orang tua telah beradaptasi dengan cepat dalam mengatasi kesenjangan pembelajaran. Langkah-langkah yang harus ditempuh adalah memberikan keterampilan belajar pada anak-anak di rumah. ${ }^{13}$ Sehingga diperlukan cara keluarga untuk menyesuaikan dan beradaptasi dengan perubahan dan kesulitan. ${ }^{14}$

Dukungan yang tidak memadai dari orang tua untuk kegiatan belajar mengurangi kemungkinan persepsi negatif nara didik tentang proses daring di masa depan. ${ }^{15}$ Dampak psikologis belajar di rumah adalah isolasi sosial, ketakutan akan infeksi, frustrasi, kebosanan, informasi yang tidak memadai, dan tekanan keuangan. ${ }^{16}$

https://ejournal.staknkupang.ac.id/ojs/index.php/te uo/article/view/33.

13 Shelina Bhamani et al., "Home Learning in Times of COVID: Experiences of Parents," Journal of Education and Educational Development 7, no. 1 (July 7, 2020): 9-26, accessed July 7, 2021, https://journals.iobmresearch.com/index.php/JoEE D/article/view/3260.

14 Rebecca L. Brock dan Lauren M. Laifer, "Family Science in the Context of the COVID-19 Pandemic: Solutions and New Directions," Family Process 59, no. 3 (September 1, 2020): 10071017, accessed July 7, 2021, https://onlinelibrary.wiley.com/doi/full/10.1111/fa mp. 12582.

${ }^{15}$ Xinyun $\mathrm{Hu}$ et al., "Technology Integration for Young Children during COVID-19: Towards Future Online Teaching," British Journal of Educational Technology 52, no. 4 (July 1, 2021): 1513-1537, accessed July 7, 2021, https://berajournals.onlinelibrary.wiley.com/doi/full/10.1111/ bjet.13106.

16 Katriona O'Sullivan et al., "Exploring the Impact of Home-Schooling on the Psychological Wellbeing of Irish Families During the Novel Coronavirus (COVID-19) Pandemic: A Qualitative Study Protocol:," International Journal of Qualitative Methods 19, no. 1 (December 23, 2020): 1-6, accessed July 7, 2021, https://journals.sagepub.com/doi/full/10.1177/160 9406920980954. 
Jadi orang tua harus menyediakan waktu dalam mendampingi anak, seperti disiplin waktu, belajar tepat waktu, dan menilai kegiatan belajar anak. ${ }^{17}$ Kendala utama orang tua dalam mendampingi anak adalah pembagian waktu dan penguasaan aplikasi menjadi problem utama dalam pelaksanaan pembelajaran daring. ${ }^{18}$ Penelitian Dini Kurniasari dan Maningtyas menemukan keterlibatan orang tua dalam pembelajaran jarak jauh selama pandemi Covid-19 berada pada kategori baik. ${ }^{19}$ Pada kesempatan belajar daring, orang tua dapat mendampingi dan membantu anak belajar dengan membuat jadwal belajar yang teratur, mengerjakan pekerjaan rumah, dan melatih anak mandiri. ${ }^{20}$

17 Mitra Binariang Lase and Talizaro Tafonao, "Urgenitas Pengawasan Orang Tua Dalam Mendampingi Psikologi Anak Selama Belajar Daring Di Masa Pandemi," XAIRETE: Jurnal Teologi dan Pendidikan Kristiani 1, no. 1 (July 2021): 15-27, accessed July 16, 2021, http://ejournal.sttkai.ac.id/index.php/xairete/article/view/ 2.

${ }^{18}$ Saripah Anum Harahap, Dimyati Dimyati, dan Edi Purwanta, "Problematika Pembelajaran Daring Dan Luring Anak Usia Dini Bagi Guru Dan Orang Tua Di Masa Pandemi Covid 19," Jurnal Obsesi : Jurnal Pendidikan Anak Usia Dini 5, no. 2 (January 20, 2021): 1825-1836, accessed September 7, 2021, https://obsesi.or.id/index.php/obsesi/article/view/1 013.

19 Dini Kurnia Sari dan Rosyidamayani T. Maningtyas, "Parents' Involvement in Distance Learning During the Covid-19 Pandemic," in Proceedings of the 2nd Early Childhood and Primary Childhood Education (ECPE 2020) (Atlantis Press, 2020), 94-97, accessed September 7, 2021, https://www.atlantispress.com/proceedings/ecpe-20/125946138.

20 Nur Hanifah dan Alief Budiyono, "Pendampingan Orang Tua Untuk Mendisiplinkan Anak Belajar Selama Masa Pandemi," Ghaidan: Jurnal Bimbingan Konseling Islam dan
Orang tua mengatakan bahwa proses bimbingan anak belajar di rumah terdapat berbagai kendala, yaitu: mengenai kesibukan orang tua, tingkat pendidikan orang tua, alat atau media pembelajaran, dan kuota internet yang tidak memadai. Berdasarkan permasalahan di atas, penulis akan mengulas pendampingan orang tua terhadap anak belajar dari rumah selama pandemi covid 19.

Observasi yang dilakukan di Sekolah Dasar Negeri (SD) Bertingkat Oebobo II Kupang. Peneliti menemukan permasalahan aktual yang terjadi di dalamnya yaitu: kebanyakan orang tua menyangka peran serta mereka dalam pembelajaran anak cuma menanggung biaya pembelajaran, menyediakan prasarana serta kebutuhan modul. Bahkan sedikitnya pengawasan orang tua tentang kemajuan pembelajaran anak-anaknya menjadi kendala dalam proses belajar. Sehingga anak-anak seharusnya mendapat perhatian serius dalam proses pembelajaran.

\section{Metode}

Studi ini menggunakan pendekatan kualitatif deskriptif. Informasi yang didapat merupakan hasil observasi, tanya jawab, pengambilan gambar, analisa akta, serta catatan lapangan. Riset, dimulai dari pengumpulan informasi sampai analisa data dan pelaporan temuan, dipandu oleh prinsip-prinsip metodologis yang menekankan keterbukaan. $^{21} \quad$ Informasi itu

Kemasyarakatan 5, no. 1 (January 1, 2021): 1-12, accessed September 7, 2021, http://jurnal.radenfatah.ac.id/index.php/ghaidan/ar ticle/view/6458.

${ }^{21}$ Annelie J. Sundler et al., "Qualitative Thematic Analysis Based on Descriptive Phenomenology," Nursing Open 6, no. 3 (July 1, 2019): 733-739, accessed July 2021, https://onlinelibrary.wiley.com/doi/full/10.1002/n op2.275. 
dideskripsikan menurut indikasi, kejadian, peristiwa yang berlangsung pada saat ini. Riset ini tujuannya untuk mendeskripsikan mengenai seluruh aktivitas suatu populasi.

Peneliti mengidentifikasi masalah yang ada dalam suatu unit, organisasi, atau suatu populasi. ${ }^{22}$ Sampel yang dipilih sebanyak 5 Orang tua. Pemilihan sampel ini menggunakan teknik purposive sampling. Teknik sampling pada penelitian kualitatif bertujuan untuk menjaring sebanyak mungkin informasi dari pelbagai sumber data dan merinci kekhususan yang ada dalam pelbagai informasi. ${ }^{23}$ Lokasi penelitian diadakan di SD Bertingkat Oebobo. Alasan pemilihan SD bertingkat Oebobo II, Kota Kupang karena penerapan metode daring baru pertama kali diperkenalkan. ${ }^{24}$

Langkah dalam menganalisis fenomena pada riset kualitatif deskriptif ialah merujuk pada pendapat pemikir Miles dan Huberman, pengurangan, penyajian, dan penyimpulan data. ${ }^{25}$ Kegiatan analisis data dalam penelitian ini didasarkan pada alur analisis tersebut.

\section{Hasil dan Pembahasan}

Berdasarkan hasil penelitian di Sekolah Dasar Inpres Bertingkat Oebobo 2 Kota Kupang tahun pelajaran 2021/2022. Peneliti memaparkan peran orang tua dalam belajar, sebagai berikut:

22 Sandra L. Siedlecki, "Understanding Descriptive Research Designs and Methods," Clinical Nurse Specialist 34, no. 1 (January 1, 2020): 8-12, accessed July 8, 2021, https://journals.lww.com/cns-

journal/Fulltext/2020/01000/Understanding_Descr iptive_Research_Designs_and.4.aspx.

${ }^{23}$ Lexy J. Moleong, Metode Penelitian Kualitatif

(Bandung: Remaja Rosdakarya, 2006). 224

${ }^{24}$ Helaluddin dan Hengki Wijaya, Analisis Data Kualitatif (Makassar: Sekolah Tinggi Teologi Jaffray, 2019), 19.

${ }^{25}$ Sugiyono, Metode Peneltian Kombinasi (Mixed Method) (Bandung: Alfabeta, 2015), 81.

\section{A. Pendampingan Orang tua Membimbing Anak Belajar Dari Rumah}

Orang tua telah mengenali kedudukan mereka selaku orang tua dalam mengusahakan kesuksesan pembelajaran anak-anak mereka. Wali Kelas Siswa Kelas VI, Perpetua Kua mengatakan bahwa Orang tua memiliki peran yang sangat penting yakni, mengajari anak belajar. Orang tua Angel Agustina Bandie, Christian. S. Pau Adu dan Valentino C. Mali, mengatakan bahwa anak diajari beberapa materi yang dipelajari, meskipun terkadang kewalahan. Orang tua Nikita Sasla Valeria, mengatakan bahwa selama masa proses belajar tatap muka maupun daring, orang tua tidak bersedia melatih diri untuk menambah pengetahuan.

Pendampingan berkualitas tinggi dengan terlibat dalam aktivitas anak memiliki positif selama interaksi membaca bersama. ${ }^{26}$ Ibu-ibu mengeluh dengan cara belajar yang disajikan melalui youtube dan materi yang disediakan dalam Google Class Room. Hal ini yang memunculkan kecemasan Orang tua yang sama sekali belum mengerti dengan materi yang diajarkan lewat virtual, khususnya pelajaran matematika. ${ }^{27}$ Penelitian Ahmad Susanto

\footnotetext{
${ }^{26}$ Shayl F. Griffith dan David H. Arnold, "Home Learning in the New Mobile Age: Parent-Child Interactions during Joint Play with Educational Apps in the US," Journal of Children and Media 13, no. 1 (2018): 1-19, accessed July 8, 2021, https://www.tandfonline.com/doi/abs/10.1080/174 82798.2018.1489866.

${ }^{27}$ Imas Mastoah dan Zulaela MS, "Kendala Orang Tua Dalam Mendampingi Anak Belajar Pada Masa Covid 19 Di Kota Serang | As-Sibyan: Jurnal Pendidikan Anak Usia Dini," As-Sibyan: Jurnal Pendidikan Anak Suia Dini 5, no. 2 (2020): 121-128, accessed July 16, 2021, http://jurnal.uinbanten.ac.id/index.php/assibyan/ar ticle/view/3663.
} 
menemukan bahwa bimbingan orang tua dan kecerdasan emosional berkontribusi $64,2 \%$ terhadap prestasi belajar siswa. ${ }^{28}$

Jadi orang tua dan guru perlu bersinergi selama proses belajar anak usia dini pada masa pandemi COVID-19 menjadi kuncinya. ${ }^{29}$ Kedudukan orang tua sungguh diperlukan dalam mengajari anak belajar serta mendampingi anak belajar. Inovasi dan daya cipta guru dalam mempraktikkan alat pembelajaran daring serta proaktif dalam berkomunikasi dengan orang tua. ${ }^{30}$

Orang tua memiliki peran dalam memenuhi kebutuhan anak, pengawasan, semangat, serta fasilitator sarana. ${ }^{31}$ Orang tua tidak hanya berperan selaku tempat pembelajaran anak yang awal serta mendasar, namun dapat mewujudkan sifat, memiliki budi yang baik namun

28 Ahmad Susanto, "The Effect of Parental Guidance and Emotional Intelligence on Learning Achievement in Social Science," Journal of Family Sciences 4, no. 2 (February 17, 2019): 120-129, accessed July 8, 2021, https://journal.ipb.ac.id/index.php/jfs/article/view/ 28430.

29 Mardi Fitri dan Muhammad Abdul Latif, "Adaptive Learning for Early Childhood Education during the COVID-19 Pandemic in Aceh Jaya District: Online vs. Offline," Al-Athfal: Jurnal Pendidikan Anak 7, no. 1 (June 29, 2021): 27-38, accessed July 8, 2021, http://ejournal.uinsuka.ac.id/tarbiyah/alathfal/article/view/3385.

30 Siti Lathifatus Sun'iyah, "Sinergi Peran Guru Dan Orang Tua Dalam Mewujudkan Keberhasilan Pembelajaran PAI Tingkat Pendidikan Dasar Di Era Pandemi Covid-19," DAR EL-ILMI : Jurnal Studi Keagamaan, Pendidikan dan Humaniora 7, no. 2 (October 19, 2020): 1-16, accessed July 16, 2021, http://www.ejurnal.unisda.ac.id/index.php/dar/article/view/207 3.

${ }^{31}$ Wiwin Yulianingsih et al., "Keterlibatan Orang tua Dalam Pendampingan Belajar Anak Selama Masa Pandemi Covid-19," Jurnal Obsesi : Jurnal Pendidikan Anak Usia Dini 5, no. 2 (October 15, 2020): 1138-1150, https://obsesi.or.id/index.php/obsesi/article/view/7 40. memiliki kedudukan selaku guru kedua untuk anak dalam belajar di rumah. ${ }^{32}$ Orang tua memerlukan panduan mendampingi kegiatan anak selama pandemi. ${ }^{33}$

Pendampingan orang tua dalam menuntun anak belajar dari rumah memiliki tingkat stres yang tinggi. Sehingga mempengaruhi orang tua dalam membimbing proses pembelajaran. ${ }^{34}$ Cara pendampingan pembelajaran dapat melalui games, storytelling, dan penugasan serta supervisi. ${ }^{35}$

Motivasi yang diberikan orang tua kepada anak yang ada di Sekolah Dasar Inpres Bertingkat Oebobo 2 Kota Kupang

${ }^{32}$ Selfi Lailiyatul Iftitah dan Mardiyana Faridhatul
Anawaty, "Peran Orang Tua Dalam Mendampingi
Anak Di Rumah Selama Pandemi Covid 19," JCE
(Journal of Childhood Education) 4, no. 2
(September 9, 2020): 71-81, accessed July 8,
2021,
http://journalfai.unisla.ac.id/index.php/jce/article/v
iew/256.
${ }^{33}$ Eka Rahayu, Vivin Agustin Anggraini, dan Siti
Nurhasanatul Islam, "Peran Orang Tua Dalam
Pendampingan Anak Usia SD/MI Dalam
Pembelajaran Online Di Saat Pandemi Covid-19,"
Auladuna: Jurnal Prodi Pendidikan Guru
Madrasah Ibtidaiyah 3, no. 1 (May 8, 2021): 37-
49, accessed July 16, 2021, http://ejournal.inaifas.ac.id/index.php/auladuna/art icle/view/477.

34 Ellya Susilowati dan Mira Azzasyofia, "The Parents Stress Level in Facing Children Study From Home in the Early of COVID-19 Pandemic in Indonesia," International Journal of Science and Society 2, no. 3 (July 5, 2020): 1-12, accessed July 8, 2021, http://ijsoc.goacademica.com/index.php/ijsoc/artic le/view/117.

35 Shokhib Rahmania, Retno Wijayanti, dan Shiddiq Luqman Hakim, "Strategi Orang Tua Dalam Pendampingan Belajar Anak Selama Pandemi Covid-19," Literasi: Jurnal Kajian Keislaman Multi-Perspektif 1, no. 1 (January 4, 2021): 99-110, accessed July 16, 2021, http://ejournal.iainsurakarta.ac.id/index.php/literas i/article/view/3259. 
berpautan dengan harapan-harapan pada anak bimbingan supaya jadi orang yang bermanfaat. Bentuk dari motivasi yang diberikan yaitu, orang tua menyerahkan reward seperti uang jajan, baju serta mainan untuk anaknya yang giat. Hal itu memungkinkan untuk dikembangkannya tingkat pencapaian atau bentuk keberhasilan dalam proses pencapaian belajar anak dari rumah anak didik. Mereka mendampingi anak didik disetiap proses pembelajaran yang ada. Hampir semua responden dari penelitian di Sekolah Pasar Inpres Bertingkat Oebbobo II Kota Kupang, menerangkan mengenai dorongan yang berhubungan dengan perubahan pendampingan orang tua anak belajar dari rumah pada diri anak didik.

Orang tua yang memperhatikan dan memotivasi sangat berkaitan dengan hasil belajar. ${ }^{36}$ Karena itu, keluarga yang bahagia sangat memengaruhi perkembangan emosi anak. ${ }^{37}$ Ada orang tua yang kurang memberi perhatian pada prosedur belajar daring pada era pandemi covid- 19 sebab beban ekonomi keluarga, kurang mengerti aplikasi pembelajaran online, serta merasa terbeban dengan kewajiban anak yang diserahkan oleh guru. ${ }^{38}$ Ini berarti dalam membimbing

36 Dessy Indah Saputri, Joko Siswanto, dan Sukamto, "Pengaruh Perhatian Orang Tua Dan Motivasi Terhadap Hasil Belajar," Jurnal Pedagogi dan Pembelajaran 2, no. 3 (August 13, 2019): 369-376, accessed July 9, 2021, https://ejournal.undiksha.ac.id/index.php/JP2/artic le/view/19285.

37 Riska Handayani, "Pengaruh Lingkungan Tempat Tinggal Dan Pola Asuh Orang tua Terhadap Motivasi Belajar Siswa Sekolah Dasar," Jurnal Tunas Bangsa 6, no. 1 (February 28, 2019): 15-26, accessed July 9, 2021 , https://ejournal.bbg.ac.id/tunasbangsa/article/view 1916.

${ }^{38}$ Farid Wajdi, "Manajemen Perkembangan Siswa SD Melalui Peran Guru Dan Orang Tua Pada Masa Pandemi," Jurnal Administrasi dan Manajemen Pendidikan 1, no. 3 (August 28, 2018): 302-312, accessed July 16, 2021, anak belajar di rumah, orang tua perlu untuk berperan sebagai edukator dan guru di rumah. Disini orang tua berperan sebagai tokoh yang memberikan dorongan, motivasi, dukungan, dan pengarahan.

\section{B. Bentuk Pendampingan Orang Tua Kepada Anak Saat Belajar Dari Rumah}

Peneliti mendapati bahwa bentuk pendampingan orang tua membimbing anak belajar dari rumah telah dilakukan oleh orang tua, namun tetap dengan keterbatasan yang ada. Wali Kelas Siswa Perpetua Kua mengatakan, ada kesulitan yang dihadapi orang tua dalam membantu anak dikarenakan latar belakang pendidikan orang tua. Pendampingan, orang tua menyediakan fasilitas belajar bagi anak-anak. Fasilitas yang dimaksud adalah fasilitas yang seadanya seperti, media belajar, alat tulis, buku pelajaran, handphone, dan kuota internet.

Orang tua Angel Agustina Bandie, Zenia Pah, Christin. S. Pan Adu, Nikita Sasla Valeria memaparkan, tiap orang dengan kerangka pembelajaran yang beda tentu tidak seluruh memahami ilmu disitulah kesulitan yang muncul. Jadi perlu memasukkan pengalaman pembelajaran berbasis teknologi jarak jauh dan aktivitas daring di sekolah secara rutin. ${ }^{39}$

Penelitian pada proses belajar IPA kelas 6 SDN 02 Ujan Mas

http://journal2.um.ac.id/index.php/jamp/article/vie w/17229.

${ }^{39}$ Tamar Shamir-Inbal dan Ina Blau, "Facilitating Emergency Remote K-12 Teaching in ComputingEnhanced Virtual Learning Environments During COVID-19 Pandemic - Blessing or Curse?:," Journal of Educational Computing Research (February 9, 2021): 1-19, accessed July 19, 2021, https://journals.sagepub.com/doi/full/10.1177/073 5633121992781. 
memperlihatkan korelasi cukup dalam meningkatkan hasil belajar siswa. ${ }^{40}$ Sarana belajar ini dapat menolong mempermudah anak dalam cara belajar alhasil anak tidak memperoleh gangguan dalam belajar yang dilaksanakan dari rumah.

Ketika anak belajar di rumah, pengawasan kegiatan belajar dilakukan oleh orang tua. Orang tua memonitor aktivitas belajar anak. Mereka dapat mengenali penguasaan anak terhadap materi yang dipelajari. Jadi keluarga perlu beradaptasi dengan sistem pembelajaran daring. ${ }^{41}$ Namun tidak ditemukan perbedaan signifikan keluarga selama proses karantina dan frekuensi tinggal atau keluar rumah. ${ }^{42}$

Agar anak dapat mengunakan waktu belajar dengan baik, orang tua berperan mendampingi dan membantu anak dalam mengatasi kesulitan belajar. Orang tua bertanggung jawab memenuhi peran pendampingan, sehingga anak mendapat pengajaran dan bimbingan menjadi modal bagi mereka menjalani

40 Diah Rina Miftakhi dan Feri Ardiansah, "Peranan Orang Tua Siswa Dalam Melaksanakan Pendampingan Pembelajaran Dari Rumah Secara Online," JOEAI:Journal of Education and Instruction 3, no. 2 (November 22, 2020): 151158, accessed July 9, 2021, https://journal.ipm2kpe.or.id/index.php/JOEAI/art icle/view/1726.

${ }^{41}$ Nourma Ulva Kumala Devi, “Adaptasi Pranata Keluarga Pada Proses Pembelajaran E-Learning Dalam Menghadapi Dampak Pandemi Covid-19," Publicio: Jurnal Ilmiah Politik, Kebijakan dan Sosial 2, no. 2 (July 8, 2020): 1-6, accessed July 9 , 2021 , https://ejournal.upm.ac.id/index.php/public/article/ view/599.

42 Halil Uzun, Nezahat Hamiden Karaca, dan Şermin Metin, "Assesment of Parent-Child Relationship in Covid-19 Pandemic," Children and Youth Services Review 120, no. 1 (January 1, 2021): 1-11, accessed July 19, 2021, https://www.sciencedirect.com/science/article/abs/ pii/S0190740920321708. kehidupan sekarang dan akan datang. ${ }^{43}$ Minimnya pengetahuan yang dimiliki oleh orang tua menjadi faktor penghambat dalam proses pembelajaran daring. ${ }^{44}$ Ini menunjukkan bahwa orang tua memiliki kesadaran akan pentingnya bentuk-bentuk pengawasan orang tua bagi anak di rumah.

Selain berperan sebagai pendidik, guru dan motivator bagi anak di rumah orang tua juga perlu menyediakan sarana atau fasilitas belajar anak di rumah. Sesuai dengan apa yang dikemukakan Afiatin Nisa berjudul "Pengaruh Perhatian Orang Tua dan Minat Belajar Siswa Terhadap Prestasi Belajar Ilmu Pengatahuan", bahwa ada tiga hal yang harus disediakan orang tua dalam membimbing anak belajar yaitu: pertama, menyediakan kesempatan sebaik-baiknya kepada anak. Kedua, menyediakan informasi relevan yang sesuai dengan bakat dan minat anak. Ketiga, menyediakan fasilitas belajar belajar serta membantu kesulitan belajarnya. ${ }^{45}$ Rational Emotive Behavior Therapy cukup mengubah perilaku dan rasionalitas

\footnotetext{
43 Asmat Purba, "Tanggung Jawab Orang Tua Kristen Dalam Mendidikan Anak Menyikapi Pandemi Covid-19," EPIGRAPHE: Jurnal Teologi dan Pelayanan Kristiani 4, no. 1 (May 29, 2020): 86-97, accessed July 9, 2021, http://jurnal.stttorsina.ac.id/index.php/epigraphe/ar ticle/view/148.

${ }^{44}$ Rossa Isnaeni Mutik et al., "Peran Serta Orang Tua Dalam Proses Pembelajaran Matematika Dengan E-Learning Di Masa Pandemi Covid-19," Jurnal Ilmiah Hubungan Internasional 1, no. 2 (2020): 131-137, accessed July 19, 2021, http://jom.untidar.ac.id/index.php/mathlocus/articl e/view/1083.

${ }^{45}$ Afiatin Nisa, "Pengaruh Perhatian Orang Tua Dan Minat Belajar Siswa Terhadap Prestasi Belajar Ilmu Pengetahuan Sosial," Faktor : Jurnal Ilmiah Kependidikan 2, no. 1 (May 16, 2017): 19, accessed July 9, 2021, https://journal.lppmunindra.ac.id/index.php/Faktor /article/view/370.
} 
atau pola pikir dalam membantu belajar anak. $^{46}$

Bentuk-bentuk pendampingan orang tua terhadap anak dalam melaksanakan pembelajaran dari rumah merupakan hal yang penting untuk dilakukan. Oleh karena dengan adanya bentuk pendampingan yang dilakukan oleh orang tua terhadap anak. Maka pembelajaran yang dilakukan dari rumah dapat berjalan dengan baik dan pada akhirnya baik anak maupun orang tua mendapatkan hasil yang baik pula.

Penerapan strategi pembelajaran di masa pandemi Covid ini adalah dengan pembelajaran di rumah yakni, metode daring dan offline. ${ }^{47}$ Dalam membimbing anak belajar dari rumah, salah satu faktor pendudukung adalah fasilitas belajar. Dari hasil penelitian di Sekolah Pasar Inpres Bertingkat Oebbobo II Kota Kupang, terlihat bahwa perhatian orang tua dalam perannya sebagai fasilitator telah dilakukan orang tua dalam memfasilitasi anak dalam belajar namun masih dengan fasilitas belajar yang seadanya.

Orang tua yang mendampingi anak sangat mempengaruhi kemandirian anak belajar dari rumah. ${ }^{48}$ Orang tua

46 Sela Pebriyanti, "Implementasi Rational Emotive Behavior Therapy Pada Orang tua Dalam Mendampingi Anak Belajar Masa Covid-19," Golden Age: Jurnal Ilmiah Tumbuh Kembang Anak Usia Dini 5, no. 2 (June 30, 2020): 63-70, accessed July 19, 2021, http://202.0.92.5/tarbiyah/goldenage/article/view/3 245.

47 Eko Suhendro, "Strategi Pembelajaran Pendidikan Anak Usia Dini Di Masa Pandemi Covid-19," Golden Age: Jurnal Ilmiah Tumbuh Kembang Anak Usia Dini 5, no. 3 (September 30, 2020): 133-140, accessed July 9, 2021, http://ejournal.uin-

suka.ac.id/tarbiyah/goldenage/article/view/3394.

48 Ratna Pangastuti et al., "Pengaruh Pendampingan Orang tua Terhadap Kemandirian Dan Tanggung Jawab Anak Selama Belajar Dari Rumah," JECED : Journal of Early Childhood dapat memanfaatkan perangkat elektronik sebagai sarana belajar di rumah dan belajar metode yang menyenangkan bagi anak sesuai usia perkembangannya. ${ }^{49}$ Fasilitas belajar yang disediakan dalam proses bimbingan belajar merupakan hal yang penting dan perlu disediakan.

\section{Kesulitan dalam Membimbing Anak Belajar dari Rumah}

Kesusahan yang dialami orang tua dalam proses belajar dari rumah seperti minimnya anak didik dalam menguasai modul yang diperoleh pada saat belajar. Alhasil orang tua diwajibkan menekuni modul yang bukan bidangnya. Sehingga orang tua selaku fasilitator belum optimal melaksanakan kedudukannya selaku fasilitator anak. Pemenuhan keperluan sarana anak masih sungguh kurang, seperti sarana belajar, buku, handphone dan kuota sehingga pembelajaran yang efisien adalah menstimulus siswa belajar sesuai dengan tema pembelajaran. ${ }^{50}$

Banyak orang tua belum menguasai teknologi. Sehingga tidak dapat membimbing dan mendampingi secara maksimal anak belajar. Hambatan

Education and Development 2, no. 2 (December 31, 2020): 132-146, accessed July 9, 2021, http://jurnalftk.uinsby.ac.id/index.php/JCED/articl e/view/727.

${ }^{49}$ Rahmatika Kayyis, Nihayati, dan Binti Anisaul Khasanah, "Menciptakan Pembelajaran Menyenangkan Di Rumah Pada Era Pandemi Covid-19," Bagimu Negeri: Jurnal Pengabdian Kepada Masyarakat 4, no. 1 (2020): 1-8, accessed July 9, 2021, https://ejournal.umpri.ac.id/index.php/bagimunege ri/article/view/1389.

${ }^{50}$ I Putu Ayub Darmawan et al., "Upaya Sekolah Dan Keterlibatan Orang Tua Dalam Pembelajaran Di Masa Pandemi Covid-19," Jurnal Komunikasi Pendidikan 5, no. 2 (July 9, 2021): 175-185, accessed July 2021, http://journal.univetbantara.ac.id/index.php/komdi k/article/view/1254. 
lain adalah pengeluaran pembelian kuota. Pada proses belajar daring, Orang tua mengeluhkan masalah kuota yang boros. Orang tua mengalami rasa kesukaran dalam menyampaikan pemahaman materi kepada anak. Karena orang tua tidak begitu paham dengan metode pembelajaran. Dalam proses belajar, anak terkadang mudah bosan dan tidak semangat. Ada beberapa orang tua yang bisa menggunakan metode pembelajaran, yaitu bermain dan tanya jawab.

Kesukaran yang dialami orang tua dalam proses belajar dari rumah mencakup: 1) konteks pendidikan orang tua; 2) tingkatan ekonomi orang tua; 3) tipe profesi orang tua ; 4) durasi yang ada; 5) jumlah keluarga.

Peran orang tua selama masa covid-19 yakni: menetapkan kalau keperluan makan serta vitamin anak terwujud sepanjang pandemi covid 19. Orang tua membimbing anak melakukan tugas- tugas serta mengambil alih kedudukan guru di sekolah. ${ }^{51}$

Pencapaian Kriteria Ketuntasan

Mninimal (KKM) siswa kelas IV memperlihatkan belajar dari rumah siswa kelas VI Sekolah Dasar Inpres Bertingkat Oebobo II, dapat melampaui target lebih dari $85 \%$ siswa mencapai KKM. Anita Wardani membuktikan kendala orang tua dalam menemani anak berajar di rumah pada era pandemi Covid 19 yakni minimnya penjelasan bahan oleh Orang tua dalam meningkatkan perhatian belajar. Orang tua tidak mempunyai waktu yang banyak mendampingi anak

${ }^{51}$ Inom Nasution dan Suharian, "Peran Orang Tua Terhdap Anak Dalam Program Belajar Dari Rumah Di Masa Pandemi Covid-19," Visipena 11, no. 2 (December 31, 2020): 266-280, accessed July 16, 2021, https://ejournal.bbg.ac.id/visipena/article/view/115 4. sebab wajib bertugas. Orang tua juga kesulitan menggunakan gadget. ${ }^{52}$

Ada lima peran penting orang tua dalam pendidikan anak, yaitu: 1) Fungsi keimanan; 2) Fungsi edukatif; 3) Fungsi sosialisasi; 4) Fungsi afeksi. ${ }^{53}$ Hal ini memperlihatkan bahwa peran orang tua belajar bersama anak di rumah mempunyai pengaruh besar terhadap proses mencapai hasil belajar yang maksimal.

\section{Kesimpulan}

Pendampingan orang tua dalam membimbing anak belajar dari rumah didapatkan yakni pertama, melaksanakan dua peran sekaligus pertama menjadi orang tua dalam mendidik anak dan kedua menjadi guru bagi anak di rumah, yaitu sebagai guru di rumah dan orang tua menyediakan sarana dan prasarana bagi anak serta mengarahkan anak sesuai dengan bakat dan minat yang dimiliki oleh masing-masing anak. Kedua, bentukbentuk pendampingan yang diberikan seperti; adanya pengadaan fasilitas belajar, perhatian yang cukup, pemantauan terhadap pengontrolan waktu, dan pengawasan serta mengatasi kesulitan-kesulitan anak dalam belajar. Ini telah jadi unsur yang wajib dalam

52 Anita Wardani dan Yulia Ayriza, "Analisis Kendala Orang Tua Dalam Mendampingi Anak Belajar Di Rumah Pada Masa Pandemi Covid-19," Jurnal Obsesi : Jurnal Pendidikan Anak Usia Dini 5, no. 1 (August 22, 2020): 772-782, accessed July $\quad 15$ 2021, https://obsesi.or.id/index.php/obsesi/article/view/7 05.

53 Frans Pantan dan Priskila Issak Benyamin, "Peran Keluarga Dalam Pendidikan Anak Pada Masa Pandemi Covid-19," KHARISMATA: Jurnal Teologi Pantekosta 3, no. 1 (July 31, 2020): 1324, accessed July 29, 2021, https://www.ejournal.stajember.ac.id/index.php/kharismata/artic le/view/43. 
terwujudnya proses belajar. Ketiga, orang tua berupaya untuk menguasai peran dalam proses belajar supaya dapat mempraktikkan strategi pembelajaran. Jadi, orang tua wajib ikut serta dalam interaksi aktif dengan dengan pihak sekolah.

\section{Referensi}

Bhamani, Shelina, Areeba Zainab Makhdoom, Vardah Bharuchi, Nasreen Ali, Sidra Kaleem, dan Dawood Ahmed. "Home Learning in Times of COVID: Experiences of Parents." Journal of Education and Educational Development 7, no. 1 (July 7, 2020): 9-26. Accessed July 7 , 2021. https://journals.iobmresearch.com/in dex.php/JoEED/article/view/3260.

Brock, Rebecca L., dan Lauren M. Laifer. "Family Science in the Context of the COVID-19 Pandemic: Solutions and New Directions." Family Process 59, no. 3 (September 1, 2020): 1007-1017. Accessed July 7, 2021.

https://onlinelibrary.wiley.com/doi/f ull/10.1111/famp.12582.

Carpenter, Jeffrey P., dan Stephen Harvey. "There's No Referee on Social Media': Challenges in Educator Professional Social Media Use." Teaching and Teacher Education 86, no. 1 (November 1, 2019): 1-12. Accessed July 7, 2021. https://www.sciencedirect.com/scien ce/article/abs/pii/S0742051X193045 $5 \mathrm{X}$.

Darmawan, I Putu Ayub, Patri Alinda Nalle, Magdalena, Marderina, dan Yustina Julita. "Upaya Sekolah Dan Keterlibatan Orang Tua Dalam Pembelajaran Di Masa Pandemi Covid-19." Jurnal Komunikasi Pendidikan 5, no. 2 (July 9, 2021):
175-185. Accessed July 15, 2021. http://journal.univetbantara.ac.id/ind ex.php/komdik/article/view/1254.

Devi, Nourma Ulva Kumala. "Adaptasi Pranata Keluarga Pada Proses Pembelajaran E-Learning Dalam Menghadapi Dampak Pandemi Covid-19." Publicio: Jurnal Ilmiah Politik, Kebijakan dan Sosial 2, no. 2 (July 8, 2020): 1-6. Accessed July 9, 2021.

https://ejournal.upm.ac.id/index.php/ public/article/view/599.

Fitri, Mardi, dan Muhammad Abdul Latif. "Adaptive Learning for Early Childhood Education during the COVID-19 Pandemic in Aceh Jaya District: Online vs. Offline." $A l$ Athfal: Jurnal Pendidikan Anak 7, no. 1 (June 29, 2021): 27-38. Accessed July 8, 2021. http://ejournal.uin-

suka.ac.id/tarbiyah/alathfal/article/vi ew/3385.

Griffith, Shayl F., dan David H. Arnold. "Home Learning in the New Mobile Age: Parent-Child Interactions during Joint Play with Educational Apps in the US." Journal of Children and Media 13, no. 1 (2018): 1-19. Accessed July 8, 2021. https://www.tandfonline.com/doi/abs /10.1080/17482798.2018.1489866.

Handayani, Riska. "Pengaruh Lingkungan Tempat Tinggal Dan Pola Asuh Orangtua Terhadap Motivasi Belajar Siswa Sekolah Dasar." Jurnal Tunas Bangsa 6, no. 1 (February 28, 2019): 15-26. Accessed July 9, 2021.

https://ejournal.bbg.ac.id/tunasbangs a/article/view/916.

Hanifah, Nur, dan Alief Budiyono. "Pendampingan Orang Tua Untuk Mendisiplinkan Anak Belajar Selama Masa Pandemi." Ghaidan: 
Jurnal Bimbingan Konseling Islam dan Kemasyarakatan 5, no. 1 (January 1, 2021): 1-12. Accessed September 7, 2021. http://jurnal.radenfatah.ac.id/index.p hp/ghaidan/article/view/6458.

Harahap, Saripah Anum, Dimyati Dimyati, dan Edi Purwanta. "Problematika Pembelajaran Daring Dan Luring Anak Usia Dini Bagi Guru Dan Orang Tua Di Masa Pandemi Covid 19." Jurnal Obsesi : Jurnal Pendidikan Anak Usia Dini 5, no. 2 (January 20, 2021): 18251836. Accessed September 7, 2021. https://obsesi.or.id/index.php/obsesi/ article/view/1013.

Harwood, Valerie, dan Nyssa Murray. "Strategic Discourse Production and Parent Involvement: Including Parent Knowledge and Practices in the Lead My Learning Campaign." International Journal of Inclusive Education 23, no. 4 (April 3, 2019): 353-368. Accessed July 7, 2021. https://www.tandfonline.com/doi/abs /10.1080/13603116.2019.1571119.

Helaluddin, dan Hengki Wijaya. Analisis Data Kualitatif. Makassar: Sekolah Tinggi Teologi Jaffray, 2019.

$\mathrm{Hu}$, Xinyun, Ming Ming Chiu, Wai Man Vivienne Leung, dan Nicola Yelland. "Technology Integration for Young Children during COVID-19: Towards Future Online Teaching." British Journal of Educational Technology 52, no. 4 (July 1, 2021): 1513-1537. Accessed July 7, 2021. https://bera-

journals.onlinelibrary.wiley.com/doi/ full/10.1111/bjet.13106.

Hutahaean, Frederik Patar, dan Talizaro Tafonao. "Urgenitas Keterlibatan Orang Tua Dalam Menangani Psikologi Anak Selama Belajar Di Masa Pandemi." Kapata: Jurnal
Teologi dan Pendidikan Kristen 2, no. 1 (2021): 13-26. Accessed September 7, 2021. http://jurnalsttba.ac.id/index.php/KJTPK/article/ view/16.

Ida, Febrianti Maya, dan Hasan Maksum. "Contribution of Learning Style, Learning Creativity and Exploratory Interest to Students' Simulation and Digital Communication Learning Outcomes during the Covid-19 Pandemic." Journal of Education Technology 4, no. 4 (March 13, 2021): 404-414. Accessed July 7, 2021.

https://ejournal.undiksha.ac.id/index. php/JET/article/view/29701.

Iftitah, Selfi Lailiyatul, dan Mardiyana Faridhatul Anawaty. "Peran Orang Tua Dalam Mendampingi Anak Di Rumah Selama Pandemi Covid 19." JCE (Journal of Childhood Education) 4, no. 2 (September 9, 2020): 71-81. Accessed July 8, 2021.

http://journalfai.unisla.ac.id/index.ph p/jce/article/view/256.

Irawati, Ratrining Raras, dan Zamroni. "The Effect of Multicultural Attitude, Learning Style, and Parents' Job on the Learning Achievement of the Students." Harmoni Sosial: Jurnal Pendidikan IPS 7, no. 2 (January 2, 2020): 160169. Accessed July 7, 2021. https://journal.uny.ac.id/index.php/hs jpi/article/view/10218.

Kayyis, Rahmatika, Nihayati, dan Binti Anisaul Khasanah. "Menciptakan Pembelajaran Menyenangkan Di Rumah Pada Era Pandemi Covid19." BAGIMU NEGERI: JURNAL PENGABDIAN KEPADA MASYARAKAT 4, no. 1 (2020): 1-8. Accessed July 9, 2021. https://ejournal.umpri.ac.id/index.ph 
p/bagimunegeri/article/view/1389.

Lase, Mitra Binariang, dan Talizaro Tafonao. "Urgenitas Pengawasan Orang Tua Dalam Mendampingi Psikologi Anak Selama Belajar Daring Di Masa Pandemi." XAIRETE: Jurnal Teologi dan Pendidikan Kristiani 1, no. 1 (July 2021): 15-27. Accessed July 16, $2021 . \quad$ http://ejournal.sttkai.ac.id/index.php/xairete/ article/view/2.

Loughran, John, dan Ian Menter. "The Essence of Being a Teacher Educator and Why It Matters." Asia-Pacific Journal of Teacher Education 47, no. 3 (May 27, 2019): 216-229. Accessed July 7, 2021. https://www.tandfonline.com/doi/abs /10.1080/1359866X.2019.1575946.

Manurung, Rismag Dalena Florentina Monica Br, dan Talizaro Tafonao. "Problem Pembelajaran Online Di Masa Pandemi Terhadap Psikologi Anak Usia 10-12 Tahun." Matheteuo: Religious Studies 1, no. 1 (June 1, 2021): 20-28. Accessed September 7, 2021. https://ejournal.staknkupang.ac.id/ojs /index.php/teuo/article/view/33.

Mastoah, Imas, dan Zulaela MS. "Kendala Orang Tua Dalam Mendampingi Anak Belajar Pada Masa Covid 19 Di Kota Serang | AsSibyan: Jurnal Pendidikan Anak Usia Dini." As-Sibyan: Jurnal Pendidikan Anak Suia Dini 5, no. 2 (2020): 121-128. Accessed July 16, 2021.

http://jurnal.uinbanten.ac.id/index.ph p/assibyan/article/view/3663.

Miftakhi, Diah Rina, dan Feri Ardiansah. "Peranan Orang Tua Siswa Dalam Melaksanakan Pendampingan Pembelajaran Dari Rumah Secara Online." JOEAI:Journal of
Education and Instruction 3, no. 2 (November 22, 2020): 151-158. Accessed July 9, 2021. https://journal.ipm2kpe.or.id/index.p $\mathrm{hp} / \mathrm{JOEAI/article/view/1726.}$

Moleong, Lexy J. Metode Penelitian Kualitatif. Bandung: Remaja Rosdakarya, 2006.

Mutik, Rossa Isnaeni, Nur Annisa Firdaus, Ema Amalia Shaliha, dan Elsa Khotimah. "Peran Serta Orang Tua Dalam Proses Pembelajaran Matematika Dengan E-Learning Di Masa Pandemi Covid-19." Jurnal Ilmiah Hubungan Internasional 1, no. 2 (2020): 131-137. Accessed July $19, \quad 2021$. http://jom.untidar.ac.id/index.php/ma thlocus/article/view/1083.

Nasution, Inom, dan Suharian. "Peran Orang Tua Terhdap Anak Dalam Program Belajar Dari Rumah Di Masa Pandemi Covid-19." Visipena 11, no. 2 (December 31, 2020): 266280. Accessed July 16, 2021. https://ejournal.bbg.ac.id/visipena/art icle/view/1154.

Nisa, Afiatin. "Pengaruh Perhatian Orang Tua Dan Minat Belajar Siswa Terhadap Prestasi Belajar Ilmu Pengetahuan Sosial." Faktor : Jurnal Ilmiah Kependidikan 2, no. 1 (May 16, 2017): 1-9. Accessed July 9, 2021.

https://journal.lppmunindra.ac.id/ind ex.php/Faktor/article/view/370.

O'Sullivan, Katriona, Amy McGrane, Serena Clark, dan Kevin Marshall. "Exploring the Impact of HomeSchooling on the Psychological Wellbeing of Irish Families During the Novel Coronavirus (COVID-19) Pandemic: A Qualitative Study Protocol:" International Journal of Qualitative Methods 19, no. 1 (December 23, 2020): 1-6. Accessed 
July 7 , 2021 . https://journals.sagepub.com/doi/full /10.1177/1609406920980954.

Pangastuti, Ratna, Fifi Pratiwi, Alma'atus Fahyuni, dan Kammariyati. "Pengaruh Pendampingan Orangtua Terhadap Kemandirian Dan Tanggung Jawab Anak Selama Belajar Dari Rumah." JECED: Journal of Early Childhood Education and Development 2, no. 2 (December 31, 2020): 132-146. Accessed July 9, 2021. http://jurnalftk.uinsby.ac.id/index.ph p/JCED/article/view/727.

Pantan, Frans, dan Priskila Issak Benyamin. "Peran Keluarga Dalam Pendidikan Anak Pada Masa Pandemi Covid-19." KHARISMATA: Jurnal Teologi Pantekosta 3, no. 1 (July 31, 2020): 13-24. Accessed July 29, 2021. https://www.ejournal.stajember.ac.id/index.php/kh arismata/article/view/43.

Pebriyanti, Sela. "Implementasi Rational Emotive Behavior Therapy Pada Orangtua Dalam Mendampingi Anak Belajar Masa Covid-19." Golden Age: Jurnal Ilmiah Tumbuh Kembang Anak Usia Dini 5, no. 2 (June 30, 2020): 63-70. Accessed July $19, \quad 2021$. http://202.0.92.5/tarbiyah/goldenage/ article/view/3245.

Purba, Asmat. "Tanggung Jawab Orang Tua Kristen Dalam Mendidikan Anak Menyikapi Pandemi Covid19." EPIGRAPHE: Jurnal Teologi dan Pelayanan Kristiani 4, no. 1 (May 29, 2020): 86-97. Accessed July 9, 2021. http://jurnal.stttorsina.ac.id/index.ph p/epigraphe/article/view/148.

Rahayu, Eka, Vivin Agustin Anggraini, dan Siti Nurhasanatul Islam. "Peran Orang Tua Dalam Pendampingan
Anak Usia SD/MI Dalam Pembelajaran Online Di Saat Pandemi Covid-19." Auladuna: Jurnal Prodi Pendidikan Guru Madrasah Ibtidaiyah 3, no. 1 (May 8, 2021): 37-49. Accessed July 16, 2021.

http://ejournal.inaifas.ac.id/index.ph p/auladuna/article/view/477.

Rahmania, Shokhib, Retno Wijayanti, dan Shiddiq Luqman Hakim. "Strategi Orang Tua Dalam Pendampingan Belajar Anak Selama Pandemi Covid-19." Literasi : Jurnal Kajian Keislaman Multi-Perspektif 1, no. 1 (January 4, 2021): 99-110. Accessed July $\quad 16, \quad 2021$. http://ejournal.iainsurakarta.ac.id/ind ex.php/literasi/article/view/3259.

Rasheed, Fareeha, dan Abdul Wahid. "Learning Style Detection in ELearning Systems Using Machine Learning Techniques." Expert Systems with Applications 174, no. 1 (July 15, 2021): 1-12. Accessed July 7 , 2021. https://www.sciencedirect.com/scien ce/article/abs/pii/S095741742100215 3.

Saputri, Dessy Indah, Joko Siswanto, dan Sukamto. "Pengaruh Perhatian Orang Tua Dan Motivasi Terhadap Hasil Belajar." Jurnal Pedagogi dan Pembelajaran 2, no. 3 (August 13, 2019): 369-376. Accessed July 9, 2021.

https://ejournal.undiksha.ac.id/index. php/JP2/article/view/19285.

Sari, Dini Kurnia, dan Rosyidamayani T. Maningtyas. "Parents' Involvement in Distance Learning During the Covid-19 Pandemic." In Proceedings of the 2nd Early Childhood and Primary Childhood Education (ECPE 2020), 94-97. Atlantis Press, 2020. Accessed 
September 7,

https://www.atlantis-

press.com/proceedings/ecpe-

20/125946138.

Shamir-Inbal, Tamar, dan Ina Blau. "Facilitating Emergency Remote K12 Teaching in ComputingEnhanced Virtual Learning Environments During COVID-19 Pandemic - Blessing or Curse?:" Journal of Educational Computing Research (February 9, 2021): 1-19. Accessed July 19, 2021. https://journals.sagepub.com/doi/full /10.1177/0735633121992781.

Shibani, Antonette, Simon Knight, dan Simon Buckingham Shum. "Educator Perspectives on Learning Analytics in Classroom Practice." The Internet and Higher Education 46, no. 1 (July 1, 2020): 1-14. Accessed July 7, 2021. https://www.sciencedirect.com/scien ce/article/abs/pii/S109675162030006 3.

Siedlecki, Sandra L. "Understanding Descriptive Research Designs and Methods." Clinical Nurse Specialist 34, no. 1 (January 1, 2020): 8-12. Accessed July 8, 2021. https://journals.lww.com/cnsjournal/Fulltext/2020/01000/Underst anding_Descriptive_Research_Desig ns_and.4.aspx.

Sugiyono. Metode Peneltian Kombinasi (Mixed Method). Bandung: Alfabeta, 2015.

Suhendro, Eko. "Strategi Pembelajaran Pendidikan Anak Usia Dini Di Masa Pandemi Covid-19." Golden Age: Jurnal Ilmiah Tumbuh Kembang Anak Usia Dini 5, no. 3 (September 30, 2020): 133-140. Accessed July 9, 2021. http://ejournal.uinsuka.ac.id/tarbiyah/goldenage/article /view/3394.
Sun'iyah, Siti Lathifatus. "Sinergi Peran Guru Dan Orang Tua Dalam Mewujudkan Keberhasilan Pembelajaran PAI Tingkat Pendidikan Dasar Di Era Pandemi Covid-19." DAR EL-ILMI: Jurnal Studi Keagamaan, Pendidikan dan Humaniora 7, no. 2 (October 19, 2020): 1-16. Accessed July 16, $2021 . \quad$ http://www.ejurnal.unisda.ac.id/index.php/dar/arti cle/view/2073.

Sundler, Annelie J., Elisabeth Lindberg, Christina Nilsson, dan Lina Palmér. "Qualitative Thematic Analysis Based on Descriptive Phenomenology." Nursing Open 6, no. 3 (July 1, 2019): 733-739. Accessed July 8, 2021. https://onlinelibrary.wiley.com/doi/f ull/10.1002/nop2.275.

Susanto, Ahmad. "The Effect of Parental Guidance and Emotional Intelligence on Learning Achievement in Social Science." Journal of Family Sciences 4, no. 2 (February 17, 2019): 120129. Accessed July 8, 2021. https://journal.ipb.ac.id/index.php/jfs /article/view/28430.

Susilowati, Ellya, dan Mira Azzasyofia. "The Parents Stress Level in Facing Children Study From Home in the Early of COVID-19 Pandemic in Indonesia." International Journal of Science and Society 2, no. 3 (July 5, 2020): 1-12. Accessed July 8, 2021. http://ijsoc.goacademica.com/index.p hp/ijsoc/article/view/117.

Trust, Torrey, Jeffrey P. Carpenter, Daniel G. Krutka, dan Royce Kimmons. "\#RemoteTeaching \& \#RemoteLearning: Educator Tweeting During the COVID-19..." Journal of Technology and Teacher Education 28, no. 2 (2020): 151159. Accessed July 7, 2021. 
https://www.learntechlib.org/p/2160 94/.

Uzun, Halil, Nezahat Hamiden Karaca, dan Şermin Metin. "Assesment of Parent-Child Relationship in Covid19 Pandemic." Children and Youth Services Review 120, no. 1 (January 1, 2021): 1-11. Accessed July 19, 2021.

https://www.sciencedirect.com/scien ce/article/abs/pii/S019074092032170 8.

Veas, Alejandro, Juan-Luis Castejón, Pablo Miñano, dan Raquel GilarCorbí. "Relationship between Parent Involvement and Academic Achievement through Metacognitive Strategies: A Multiple Multilevel Mediation Analysis." British Journal of Educational Psychology 89, no. 2 (June 1, 2019): 393-411. Accessed July 7, 2021. https://bpspsychub.onlinelibrary.wile y.com/doi/full/10.1111/bjep.12245.

Wajdi, Farid. "Manajemen Perkembangan Siswa SD Melalui Peran Guru Dan Orang Tua Pada Masa Pandemi." Jurnal Administrasi dan Manajemen Pendidikan 1, no. 3 (August 28, 2018): 302-312. Accessed July 16, 2021.

http://journal2.um.ac.id/index.php/ja mp/article/view/17229.
Wardani, Anita, dan Yulia Ayriza. "Analisis Kendala Orang Tua Dalam Mendampingi Anak Belajar Di Rumah Pada Masa Pandemi Covid19." Jurnal Obsesi : Jurnal Pendidikan Anak Usia Dini 5, no. 1 (August 22, 2020): 772-782. Accessed July 15, 2021. https://obsesi.or.id/index.php/obsesi/ article/view/705.

Wraae, Birgitte, dan Andreas Walmsley. "Behind the Scenes: Spotlight on the Entrepreneurship Educator." Education + Training 62, no. 3 (April 6, 2020): 255-270.

Yulianingsih, Wiwin, Suhanadji, Rivo Nugroho, dan Mustakim. "Keterlibatan Orangtua Dalam Pendampingan Belajar Anak Selama Masa Pandemi Covid-19." Jurnal Obsesi: Jurnal Pendidikan Anak Usia Dini 5, no. 2 (October 15, 2020): 1138-1150. https://obsesi.or.id/index.php/obsesi/ article/view/740. 